\title{
Analysis of Local Financial Management Transparency Based on Websites on Local Government in Java
}

\author{
Anissa Adriana ${ }^{\bowtie}$ and Irwan Taufiq Ritonga \\ Master of Accounting, Gadjah Mada University, \\ Jl. Sosio Humaniora No.1, Caturtunggal, Depok, Sleman, Yogyakarta 55281, Indonesia \\ DOI: http://dx.doi.org/10.15294/jda.v10i1.12558
}

Received: January 4, 2018. Revised: February 20, 2018. Accepted: February 28, 2018. Published: March 15, 2018

\begin{abstract}
The aim of this research is to analyze financial management transparency of local governments in Java using scoring and rating. The financial management transparency of the local governments is scored based on presentation of local financial information uploaded on each local government's official website in Jawa in the fiscal years 2016.This research is a qualitative research with the object of research is all local government in Java. Data analysis in two levels, namely the transparency of local government financial management and identification of local government characteristics based on transparency of financial management. Data analysis in two levels, namely the transparency of local government financial management and identification of local government characteristics based on transparency of financial management. The results show that the Special Capital Region of Jakarta obtained the highest transparency index, at 58,02\% whereas Madiun Regency received the lowest transparency index, at 3,40\%. The average transparency index in Jawa for the fiscal years 2016 was still low, at only 19,59\%.The conclusion of this research is that Java regional governments consider the transparency of local financial management using less important websites because it is considered as a better thing not delivered to the public.
\end{abstract}

Keywords: transparency; good governance; local government; management of regional finance; website

\section{How to cite (APA 6th Style)}

Adriana Anissa \& Ritonga, I.T. (2018). Analysis of Local Financial Management Transparency Based on Websites on Local Government in Java. Jurnal Dinamika Akuntansi, 10(1), 13-26.

\section{INTRODUCTION}

In managing its finances, both central and local governments are expected to be able to implement the principles of good governance. In Indonesia, good governance principles or good governance embodied in Government Regulation no. 58 of 2005 on Regional Financial Management which states that the regional financial management is expected to be carried out effectively and efficiently and can be implemented in accordance with the principles of good governance that is transparent, accountable, and participative (Johnston, 2006; Marais et al., 2017).

On Government Regulation no. 58 of 2005 on Regional Financial Management, explained that transparent is a principle of openness that allows the public to know and get access to information as widely as possible about regional finances. The government regulation becomes one of the fundamental set Law no. 14 Year 2008 on Public Information Disclosure which states

Anissa Adriana $(\square)$

E-mail: adriana.anissa@gmail.com 
that every public information should be obtained by every applicant of public information quickly and timely, low cost, and simple way. To make this happens, one of the ways is to provide a website as a portal to access public information. The publication of financial statements is a key element in representing accountability of financial statements (Sargiacomo \& Gomes, 2011; Tayib, Coombs, \& Ameen, 1999; Yusuf \& Jordan, 2015). The importance of website and transparency of financial management becomes the basis of the Minister of Home Affairs in stipulating the Instruction of the Minister of Home Affairs No. 188.52 / 1797 / SJ / 2012 on Improving Transparency of Local Budget Management. In the instruction, the local government is required to provide a menu / subdomain under the name "Transparency of Local Budget Management" on the official website of the local government along with documents to be posted on it.

Although many legislations require the implementation of transparency in financial management, in practice not all are implemented by local governments. As a result, there is public dissatisfaction with the performance of local government, especially related to the transparency of its financial management. For example, riots and physical contacts occur in Kuningan District by the end of 2015 when some college students urged the DPRD to prioritize the principle of transparency and accountability in the implementation of 2016 APBD which is newly approved (http://www.kuninganterkini.com/index.php/pemerintahan/4645-imm-desak-transparansiapbd-2016.html).

The reason is until now there are still many local governments that put aside the importance of transparency of local financial management. The government as the executor of governance should also function as a giver of information related to policies, processes, and reports to the public as trust giver. The function is in line with the goal of government to citizen that is providing access to information one door on line to the community so that people can find and access information quickly and easily.

Another reason is that even though legislation relating to the obligation to realize transparency of local financial management and every document that need to be presented has been established, the central government has never undertaken an assessment and rating of transparency of local financial management based on compliance with these laws. Without assessments and ratings, local governments tend to ignore the importance of transparency and lack the competitiveness to become better in terms of financial management transparency.

Several studies have tried to assess the transparency of local financial management in Indonesia such as (Soepriyanto and Aristiani 2011), (Hermana et al. 2012), as well as (Martani \& Fitriasari, 2014) but the three studies have not yet comprehensively measured from the planning stage to reporting and accountability. The limitations are then fixed by Huwae who compiles 29 indicators of transparency measurement of local financial management and measures by one criterion namely the availability of financial information on the local government website (Huwae, 2016). Huwae's research is further complemented and adapted by Syamsul \& Ritonga (2017) using three criteria of measurement, namely availability, accessibility and timeliness of disclosure to measure the level of transparency in the three main stages of local financial management, namely planning, implementation and reporting and accountability, but the research is only conducted on provincial governments in Indonesia (Syamsul \& Ritonga, 2017).

Looking at the problems that occurs, this study aims to assess and improve the transparency of local financial management becomes important to do. This research differs from previous research because it reveals the condition of local government in an island, that is Java. The object of research in Java is more interesting to be studied because Java is the centre of economic development in Indonesia and certainly its people pay more attention to the management of local government for the prosperity of society, especially the financial management of local government. With this research, it is expected that the local government and its people can know the level and importance of local financial management transparency so that the society as principal can trust government work as agent (Lane, 2013).

Agency theory describes the relationship between company owner or shareholder as 
principal and company management as agent. Agent is the party contracted by the principal to work for the sake of principal's interest and because they are selected, principal then the agent must account for all his work to the principal (Jensen \& Meckling, 1976). In the public sector, the agency relationship takes place between the government as the agent and the community as the principal

Agency theory is built to understand and solve problems that arise when there is incomplete information when principals and agents contract. The problem of information mastery imbalance between agents and principals (asymmetry information) occurs also in the public sector. When principals optimize their oversight and can obtain important and relevant data from agents, the problem of information asymmetry can be reduced (Attila, 2012).

Good governance as a system that is transparent, accountable, fair, democratic, participative, and responsive to human needs (UNESCAP, 2009). These characteristics can be applied to all levels of government from center to region. Transparency as the availability of information to the community and clarity about government legislation (Arista, 2015). In measuring the transparency of financial management in the public sector there are several indicators that can be the basis of measurement. The main criteria in the disclosure of information ideally is the availability of budget information, the availability of sufficient information, can be accessed, and published on time (Maulana, 2013).. Based on the Instruction of the Minister of Home Affairs. 188.52 / 1797 / SJ / 2012, one way to convey effective and efficient information is to use website. Disclosure of financial documents via internet can significantly influence to increase transparency as part of financial information sources management to provide public services (Caba Pérez, Rodríguez Bolívar, and López Hernández 2014).

\section{RESEARCH METHOD}

This research used qualitative approach. The data used in this research was secondary data in the form of information / documents of regional financial management from the planning, implementation, and reporting and accountability stages of APBD of 2016 budget year. All Java local governments were chosen as research objects because Java has a considerable number of local governments when compared to several other islands, which were as many as six provinces and 113 districts / municipalities so that the regional governments of Java were the second largest after Sumatra. In addition, Java was also often used as a benchmark of progress in development and governance in Indonesia.

The study was conducted by documenting website data to analyze the transparency of local government financial management in Java in fiscal year 2016. There were 119 local governments divided into six provincial governments and 113 district / city governments assessed by the website and became objects of this research. The local government was assessed its transparency of regional financial management by looking at data, information and documents of regional financial management presented in its official website. The assessment of the website was conducted from $30^{\text {th }}$ March 2017 to $30^{\text {th }}$ May 2017.

Transparency of regional financial management was a form of government openness when loading various financial policies so that could be known and supervised by the community and various stakeholders (Syamsul \& Ritonga, 2017). Openness done by government started from the process of planning, implementation, administration, reporting, responsibility, and supervision. The research was conducted in the form of website data documentation to analyze the transparency of local financial management in all local government in Java, both provincial and district / municipality governments in fiscal year 2016.

Transparency of local financial management here was seen from four measurement criteria, namely availability, accessibility, timeliness of disclosure and frequency of local financial data/ information disclosure uploaded on each official website of local government. The assessment of transparency level was done in the planning, implementation, and reporting and accountability stages of APBD which were then ranked according to the measurement / assessment result. 
Secondary data sources were obtained from the official website of the local government in Java. In addition, other secondary data required were information related to the characteristics of local governments in Java that had the highest and the lowest level of transparency in regional financial management. The data was collected by documentation. Documentation was in accordance with this research because the research was conducted by documenting data related to transparency indicators of local financial management on the official website of the local government and to collect public documents in the form of books, news, magazines, newspapers, publications or other sources both print and on line to identify the characteristics of local governments in Java that had the highest and lowest transparency of regional financial management.

The analysis stages in this research were (1) the stage of assessment and rating of regional government financial management transparency of Java as a whole and (2) the stage of local government characteristic identification which had the highest and lowest transparency of regional financial management. Assessment of the level of local financial management transparency was conducted by using the instruments prepared by Huwae. There were 29 indicators compiled by Huwae to assess the presentation of regional financial management information / documents at the planning, implementation, and reporting and accountability stages of the APBD.

Table 1. Research Indicators

\begin{tabular}{|c|c|c|c|c|c|c|}
\hline \multirow{2}{*}{$\begin{array}{c}\text { Stages } \\
\text { Planning }\end{array}$} & \multicolumn{6}{|c|}{ Indicators } \\
\hline & Local & Budget General & Budget Priorities & Budget Work & PPKD Budget & Draft of \\
\hline \multirow{4}{*}{ Planning } & $\begin{array}{l}\text { Government } \\
\text { Work Plan }\end{array}$ & Policy & and Ceiling & Plan of SKPD & Work Plan & $\begin{array}{l}\text { Local } \\
\text { Regulations } \\
\text { on APBD }\end{array}$ \\
\hline & Local & Regulation of & Budget & Budget & & \\
\hline & Regulations on & the Regional & Implementation & Implementation & & \\
\hline & APBD & $\begin{array}{l}\text { Head on the } \\
\text { Translation of } \\
\text { APBD }\end{array}$ & $\begin{array}{l}\text { Document of } \\
\text { SKPD }\end{array}$ & $\begin{array}{l}\text { Document of } \\
\text { PPKD }\end{array}$ & & \\
\hline \multirow[t]{7}{*}{ Implementation } & Revenue & Expenditure & Financing & Draft of Local & Local & Regulation \\
\hline & Realization & Realization & Realization & Regulations on & Regulation on & of the \\
\hline & Information & & & Amendments to & Amendment & Regional \\
\hline & & & & /APBD & $\begin{array}{l}\text { Budget } \\
\text { (APBD) }\end{array}$ & $\begin{array}{l}\text { Translation } \\
\text { of the } \\
\text { Amendment } \\
\text { of APBD }\end{array}$ \\
\hline & Budget Work & General & Decree of & & & \\
\hline & Plan of APBD & Procurement & Regional Head of & & & \\
\hline & Change & Plan & $\begin{array}{l}\text { Regional Finance } \\
\text { Manager }\end{array}$ & & & \\
\hline \multirow{9}{*}{$\begin{array}{l}\text { Reporting and } \\
\text { Accountability }\end{array}$} & Regulation of & Cashflow & Budget & Budget & Balance Sheet & CaLK \\
\hline & Regional Head & Report & Realization & Realization & & of Local \\
\hline & on Accounting & & Report for all & Report for all & & Government \\
\hline & Policy & & SKPD & PPKD & & \\
\hline & Financial & Local & Local Regulation & BPK's opinion & & \\
\hline & Report of & Government & on Accountability & on Local & & \\
\hline & BUMD / & Annual & of APBD & Government & & \\
\hline & Regional & Accountability & Implementation & Financial Report & & \\
\hline & & $\begin{array}{l}\text { Performance } \\
\text { Report }\end{array}$ & & & & \\
\hline
\end{tabular}

Different from instruments prepared by Huwae, the assessment in this study only used 27 indicators where two indicators at the reporting and accountability stages namely the Regional Regulation on APBD Implementation Accountability of 2016 and BPK RI's opinion on LKPD 2016 were not used because it was assumed that until the end of the assessment date not all district / city could present it.

Huwae's study, which measured only one criterion that was availability, was complemented in this study by adding three other criteria namely accessibility, timeliness of disclosure, and frequency of local financial management documents disclosure. Information was said to be 
available if the indicator document at each stage of local financial management was available on the official website of local government, whereas if the document could be downloaded by the public, the information was said to be accessible.

Timeliness was assessed on the basis of comparative date uploads by local governments in disclosing local financial management information with the date of stipulation in accordance with the required time span. In this study, the required time span was 30 days after the local financial management documents were established. Frequency of disclosure in this research was indicated by the availability of information transparency of local financial management per indicator in certain time period. The exact time set in this study was three years back to the end of 2013. The way to assess the completeness of criteria was shown by table 2 .

Table 2. Assessment of criteria completeness

\begin{tabular}{|c|c|c|}
\hline \multicolumn{2}{|l|}{ Stages } & Action to Do \\
\hline $\begin{array}{l}\text { The initial step to } \\
\text { get the index }\end{array}$ & 1) & $\begin{array}{l}\text { Using dichotomous scores so that if the indicator was available on the website } \\
\text { then it was scored } 1 \text { for each indicator on four main criteria. If the indicator was } \\
\text { not available, inaccessible, or not timely then it was scored } 0 \text { for each indicator. } \\
\text { For the criteria of disclosure frequency if the indicator was not available it } \\
\text { would be scored } 0 \text {, if the indicator was available in one year would be scored } \\
\text { one-third, the indicator was available in two years would be scored two thirds } \\
\text { whereas if the indicator was available in three consecutive years it would be } \\
\text { scored } 1 \text {. }\end{array}$ \\
\hline & 2) & $\begin{array}{l}\text { The four main criteria had a weight of scores that would be multiplied by the } \\
\text { value obtained in each indicator. Both availability, accessibility, timeliness of } \\
\text { disclosure and frequency of disclosure had the same weight of } 0.25 \text {. }\end{array}$ \\
\hline & 3) & $\begin{array}{l}\text { The result of multiplication of weights and scores on each indicator then } \\
\text { summed to obtain the total score of each local government. }\end{array}$ \\
\hline & 4) & $\begin{array}{l}\text { The transparency index was calculated by dividing the total score obtained by } \\
\text { the expected score obtained from all indicators. }\end{array}$ \\
\hline & 5) & $\begin{array}{l}\text { Once the transparency index was known, the local government could be rated } \\
\text { according to the level of transparency it obtained. }\end{array}$ \\
\hline \multirow[t]{4}{*}{$\begin{array}{l}\text { The next step } \\
\text { if there were } \\
\text { conditions some } \\
\text { local governments } \\
\text { got the same index }\end{array}$} & 1) & $\begin{array}{l}\text { Local governments that got higher score in the reporting and accountability } \\
\text { stages would be placed on a higher level of transparency index because the } \\
\text { documents at the reporting and accounting stages have summarized the things } \\
\text { that have been outlined in the documents at the planning and implementation } \\
\text { stages. }\end{array}$ \\
\hline & 2) & $\begin{array}{l}\text { If the scores at the reporting and accountability stages were still the same, the next } \\
\text { step was to look at the scores at the implementation stage. Local governments } \\
\text { that scored higher at the implementation stage would be placed on a higher level } \\
\text { of transparency index. This was determined by consideration that most of the } \\
\text { documents at the implementation stage have also included regional financial } \\
\text { planning. }\end{array}$ \\
\hline & 3) & $\begin{array}{l}\text { If both of the above steps have been done and the score was still the same, or } \\
\text { in other words, the score obtained was the same and came from the same stage } \\
\text { namely the planning stage, then the ranking was determined in alphabetical } \\
\text { order of the name of the local government. }\end{array}$ \\
\hline & 4) & $\begin{array}{l}\text { Ranking in alphabetical order of local government name was also applicable in } \\
\text { determining the ranking of local governments that only met one indicator and } \\
\text { the only indicator was also the same owned by other local governments. }\end{array}$ \\
\hline
\end{tabular}

All local governments were then categorized based on the Open Budget Index (OBI) which was a ranking category used by the International Budget Partnership (IBP). The level of budget information disclosure category based on OBI was shown in table 3. 
Table 3. The Level of Budget Information Disclosure Category Based on Open Budget Index (OBI)

\begin{tabular}{cclc}
\hline No. & The Level of Budget Openness & \multicolumn{1}{c}{ Categories } & Scores \\
\hline \multirow{2}{*}{1} & \multirow{2}{*}{ Sufficient } & Extensive & $81-100$ \\
& & Substantial & $61-80$ \\
\multirow{2}{*}{2} & \multirow{2}{*}{ Insufficient } & Limited & $41-60$ \\
& & Minimal & $21-40$ \\
& & Scant or None & $0-20$ \\
\hline
\end{tabular}

Source: IBP (2015)

Once the level of transparency of each local government was known, it was conducted the identification of characteristics on local governments that had the highest and lowest transparency index to know the things that distinguished local governments that gott the highest and lowest predicate. Identification was only conducted on 10 district / city governments with the highest transparency index and 10 district / city governments with the lowest transparency index. If there was a provincial government which was ranked the 10th highest and 10th lowest, it would not be included in the identification because in general the provincial government had different governmental conditions with the district / city government so it could not be compared.

The identification is done by conducting literature review by looking for data and information related to the condition of regency / city government which was relevant with the evaluation of local financial management transparency. Library study as activity to conduct study and analysis to material from library such as book, research report, report result of devotion, manuscript record and so on (Ibrahim, 2015).

To maintain the validity of the data in this study, the method used is repeated checking and peer debriefing. Repeated checking was done to the official website of local government during the research date. Peer debriefing was using others to help reviewing and conducting question and answer about research so that the understanding was aligned with researchers (Creswell, 2012). Parties who became peer debriefer in this study was a student of Gadjah Mada University from Master program of Accounting in Public Sector Accounting Concentration.

\section{RESULTS AND DISCUSSIONS}

There were 119 local governments in Java that became the object of research, consisting of six provincial governments and 113 district / city governments. The 119 local governments, all of which had websites that were in active and accessible condition. The result of the assessment could be seen in the following table.

Table 4. Index and Ranking of Regional Financial Management Transparency Year 2016

\begin{tabular}{|c|c|c|c|c|c|c|}
\hline \multirow[b]{2}{*}{ No. } & \multirow{2}{*}{$\begin{array}{c}\text { Name of Local } \\
\text { Government }\end{array}$} & \multicolumn{3}{|c|}{ Stages of Local Financial Management } & \multirow[b]{2}{*}{ Total } & \multirow[b]{2}{*}{ Index $(\%)$} \\
\hline & & Planning & Implementation & $\begin{array}{l}\text { Reporting and } \\
\text { Accountability }\end{array}$ & & \\
\hline 1 & DKI Jakarta Province & 4.17 & 6.75 & 4.75 & 15.67 & 58.02 \\
\hline 2 & Bojonegoro Regency & 7.00 & 5.50 & 1.17 & 13.67 & 50.62 \\
\hline 3 & Central Java Province & 4.42 & 5.83 & 2.83 & 13.08 & 48.46 \\
\hline 4 & Malang Regency & 6.00 & 3.92 & 2.50 & 12.42 & 45.99 \\
\hline 5 & East Java Province & 4.67 & 4.83 & 2.33 & 11.83 & 43.83 \\
\hline 6 & Banyuwangi Regency & 5.00 & 5.67 & 1.08 & 11.75 & 43.52 \\
\hline 7 & Magelang City & 7.25 & 3.75 & 0.75 & 11.75 & 43.52 \\
\hline 8 & Jombang Regency & 5.67 & 4.50 & 1.25 & 11.42 & 42.28 \\
\hline 9 & Trenggalek Regency & 5.58 & 4.08 & 1.50 & 11.17 & 41.36 \\
\hline 18 & $\begin{array}{l}\text { Jurnal Dinamika Akuntansi } \\
\text { Vol. 10, No. 1, March 2018, pF }\end{array}$ & & & & & \\
\hline
\end{tabular}




\begin{tabular}{|c|c|c|c|c|c|c|}
\hline 10 & Tegal Regency & 6.42 & 3.83 & 0.92 & 11.17 & 41.36 \\
\hline 11 & D.I. Yogyakarta & 4.58 & 3.83 & 2.00 & 10.42 & 38.58 \\
\hline 12 & Bantul Regency & 3.92 & 4.83 & 1.58 & 10.33 & 38.27 \\
\hline 13 & Batang Regency & 4.58 & 4.50 & 1.08 & 10.17 & 37.65 \\
\hline 14 & Yogyakarta City & 4.92 & 3.75 & 1.33 & 10.00 & 37.04 \\
\hline 15 & Kudus Regency & 5.92 & 2.83 & 1.00 & 9.75 & 36.11 \\
\hline 16 & Cilacap Regency & 3.58 & 4.83 & 1.08 & 9.50 & 35.19 \\
\hline 17 & Pemalang Regency & 4.08 & 4.00 & 0.92 & 9.00 & 33.33 \\
\hline 18 & Banten Province & 4.17 & 3.00 & 1.58 & 8.75 & 32.41 \\
\hline 19 & Demak Regency & 2.67 & 4.50 & 1.25 & 8.42 & 31.17 \\
\hline 20 & Purworejo Regency & 4.33 & 2.33 & 1.58 & 8.25 & 30.56 \\
\hline 21 & Magelang Regency & 3.75 & 3.00 & 1.42 & 8.17 & 30.25 \\
\hline 22 & Blitar Regency & 4.83 & 2.00 & 1.33 & 8.17 & 30.25 \\
\hline 23 & Majalengka Regency & 1.00 & 5.33 & 1.58 & 7.92 & 29.32 \\
\hline 24 & Sampang Regency & 3.17 & 3.17 & 1.58 & 7.92 & 29.32 \\
\hline 25 & Bondowoso Regency & 3.58 & 3.17 & 1.08 & 7.83 & 29.01 \\
\hline 26 & West Java Province & 2.50 & 3.67 & 1.42 & 7.58 & 28.09 \\
\hline 27 & Surabaya City & 2.67 & 3.50 & 1.17 & 7.33 & 27,16 \\
\hline 28 & Bogor Regency & 1.67 & 4.67 & 0.75 & 7.08 & 26.23 \\
\hline 29 & Klaten Regency & 3.83 & 2.67 & 0.58 & 7.08 & 26.23 \\
\hline 30 & Cirebon City & 2.00 & 3.67 & 1.33 & 7.00 & 25.93 \\
\hline 31 & Rembang Regency & 2.67 & 3.25 & 0.92 & 6.83 & 25.31 \\
\hline 32 & Blitar City & 4.50 & 1.75 & 0.50 & 6.75 & 25.00 \\
\hline 33 & Wonosobo Regency & 3.92 & 1.92 & 0.83 & 6.67 & 24.69 \\
\hline 34 & Brebes Regency & 3.75 & 2.50 & 0.42 & 6.67 & 24.69 \\
\hline 35 & Sidoarjo Regency & 1.75 & 3.50 & 1.25 & 6.50 & 24.07 \\
\hline 36 & Lebak Regency & 3.00 & 3.08 & 0.42 & 6.50 & 24.07 \\
\hline 37 & Pekalongan Regency & 2.50 & 2.83 & 1.00 & 6.33 & 23.46 \\
\hline 38 & Purbalingga Regency & 2.58 & 3.25 & 0.50 & 6.33 & 23.46 \\
\hline 39 & Probolinggo City & 4.00 & 1.67 & 0.58 & 6.25 & 23.15 \\
\hline 40 & Grobogan Regency & 3.67 & 1.92 & 0.58 & 6.17 & 22.84 \\
\hline 41 & Pati Regency & 1.92 & 2.83 & 1.33 & 6.08 & 22.53 \\
\hline 42 & Kuningan Regency & 2.17 & 2.92 & 0.83 & 5.92 & 21.91 \\
\hline 43 & Bekasi City & 1.50 & 2.92 & 1.42 & 5.83 & 21.60 \\
\hline 44 & Surakarta City & 2.50 & 2.08 & 1.25 & 5.83 & 21.60 \\
\hline 45 & $\begin{array}{l}\text { Tulungagung } \\
\text { Regency }\end{array}$ & 1.92 & 3.17 & 0.75 & 5.83 & 21.60 \\
\hline 46 & Kulonprogo Regency & 2.25 & 2.08 & 1.33 & 5.67 & 20.99 \\
\hline 47 & Tangerang City & 2.92 & 1.83 & 0.83 & 5.58 & 20.68 \\
\hline 48 & Sukoharjo Regency & 2.42 & 2.25 & 0.83 & 5.50 & 20.37 \\
\hline 49 & Semarang Regency & 2.33 & 2.50 & 0.67 & 5.50 & 20.37 \\
\hline 50 & Bogor City & 2.92 & 2.08 & 0.50 & 5.50 & 20.37 \\
\hline 51 & Kendal Regency & 3.25 & 1.83 & 0.33 & 5.42 & 20.06 \\
\hline 52 & Blora Regency & 1.83 & 3.08 & 0.25 & 5.17 & 19.14 \\
\hline 53 & Banyumas Regency & 2.50 & 2.00 & 0.58 & 5.08 & 18.83 \\
\hline
\end{tabular}




\begin{tabular}{|c|c|c|c|c|c|c|}
\hline 54 & Sleman Regency & 2.00 & 2.42 & 0.58 & 5.00 & 18.52 \\
\hline 55 & Pasuruan Regency & 3.25 & 1.25 & 0.50 & 5.00 & 18.52 \\
\hline 56 & Salatiga City & 2.00 & 1.83 & 1.08 & 4.92 & 18.21 \\
\hline 57 & $\begin{array}{l}\text { Temanggung } \\
\text { Regency }\end{array}$ & 1.42 & 2.50 & 1.00 & 4.92 & 18.21 \\
\hline 58 & Serang Regency & 2.42 & 2.08 & 0.42 & 4.92 & 18.21 \\
\hline 59 & Bandung City & 1.58 & 2.17 & 1.08 & 4.83 & 17.90 \\
\hline 60 & Mojokerto Regency & 2.67 & 1.50 & 0.58 & 4.75 & 17.59 \\
\hline 61 & Situbondo Regency & 1.75 & 2.92 & 0.08 & 4.75 & 17.59 \\
\hline 62 & Kediri City & 1.50 & 2.58 & 0.58 & 4.67 & 17.28 \\
\hline 63 & Malang City & 1.25 & 2.50 & 0.83 & 4.58 & 16.98 \\
\hline 64 & Garut Regency & 1.42 & 2.50 & 0.67 & 4.58 & 16.98 \\
\hline 65 & Semarang City & 1.50 & 2.00 & 1.00 & 4,50 & 16.67 \\
\hline 66 & Karawang Regency & 1.50 & 2.67 & 0.33 & 4.50 & 16.67 \\
\hline 67 & $\begin{array}{l}\text { Banjarnegara } \\
\text { Regency }\end{array}$ & 2.00 & 1.75 & 0.67 & 4.42 & 16.36 \\
\hline 68 & $\begin{array}{l}\text { Gunungkidul } \\
\text { Regency }\end{array}$ & 2.00 & 1.75 & 0.58 & 4.33 & 16.05 \\
\hline 69 & Kebumen Regency & 1.67 & 2.17 & 0.42 & 4.25 & 15.74 \\
\hline 70 & Tangerang Regency & 0.00 & 3.17 & 1.00 & 4.17 & 15.43 \\
\hline 71 & $\begin{array}{l}\text { Tasikmalaya } \\
\text { Regency }\end{array}$ & 1.83 & 1.58 & 0.75 & 4.17 & 15.43 \\
\hline 72 & Pasuruan City & 1.17 & 2.33 & 0.58 & 4.08 & 15.12 \\
\hline 73 & Jember Regency & 3.08 & 0.92 & 0.00 & 4.00 & 14.81 \\
\hline 74 & Pekalongan City & 0.67 & 1.83 & 1.42 & 3.92 & 14.51 \\
\hline 75 & Ponorogo Regency & 1.50 & 1.83 & 0.42 & 3.75 & 13.89 \\
\hline 76 & Cirebon Regency & 1.08 & 1.83 & 0.67 & 3.58 & 13.27 \\
\hline 77 & $\begin{array}{l}\text { Pangandaran } \\
\text { Regency }\end{array}$ & 1.25 & 1.42 & 0.83 & 3.50 & 12.96 \\
\hline 78 & Lamongan Regency & 0.58 & 2.58 & 0.33 & 3.50 & 12.96 \\
\hline 79 & Depok City & 0.58 & 1.75 & 1.00 & 3.33 & 12.35 \\
\hline 80 & $\begin{array}{l}\text { Karanganyar } \\
\text { Regency }\end{array}$ & 0.67 & 2.42 & 0.25 & 3.33 & 12.35 \\
\hline 81 & Cilegon City & 0.92 & 1.83 & 0.50 & 3.25 & 12.04 \\
\hline 82 & Bandung Regency & 0.67 & 2.08 & 0.42 & 3.17 & 11.73 \\
\hline 83 & Wonogiri Regency & 1.08 & 1.50 & 0.50 & 3.08 & 11.42 \\
\hline 84 & Banjar City & 0.75 & 1.92 & 0.42 & 3.08 & 11.42 \\
\hline 85 & Mojokerto City & 1.50 & 1.33 & 0.25 & 3.08 & 11.42 \\
\hline 86 & Pandeglang Regency & 1.25 & 1.67 & 0.17 & 3.08 & 11.42 \\
\hline 87 & Bangkalan Regency & 1.75 & 1.17 & 0.08 & 3.00 & 11.11 \\
\hline 88 & Purwakarta Regency & 0.75 & 1.67 & 0.50 & 2.92 & 10.80 \\
\hline 89 & Sumenep Regency & 0.83 & 1.67 & 0.42 & 2.92 & 10.80 \\
\hline 90 & Tuban Regency & 0.42 & 2.25 & 0.25 & 2.92 & 10.80 \\
\hline 91 & Cimahi City & 0.92 & 1.83 & 0.17 & 2.92 & 10.80 \\
\hline 92 & Boyolali Regency & 1.42 & 1.17 & 0.08 & 2.67 & 9.88 \\
\hline 93 & Batu City & 0.67 & 1.50 & 0.42 & 2.58 & 9.57 \\
\hline 2 & $\begin{array}{l}\text { Jurnal Dinamika Akuntansi } \\
\text { Vol. 10, No. 1, March 2018, }\end{array}$ & & & & & \\
\hline
\end{tabular}




\begin{tabular}{|c|c|c|c|c|c|c|}
\hline 94 & Tegal City & 0.75 & 1.42 & 0.42 & 2.58 & 9.57 \\
\hline 95 & Kediri Regency & 0.67 & 1.58 & 0.33 & 2.58 & 9.57 \\
\hline 96 & Subang Regency & 1.33 & 1.08 & 0.08 & 2.50 & 9.26 \\
\hline 97 & Sumedang Regency & 0.58 & 1.42 & 0.42 & 2.42 & 8.95 \\
\hline 98 & Pacitan Regency & 0.75 & 1.25 & 0.25 & 2.25 & 8.33 \\
\hline 99 & Probolinggo Regency & 0.25 & 1.58 & 0.33 & 2.17 & 8.02 \\
\hline 100 & $\begin{array}{l}\text { Tangerang Selatan } \\
\text { City }\end{array}$ & 0.17 & 1.58 & 0.33 & 2.08 & 7.72 \\
\hline 101 & Ngawi Regency & 0.00 & 1.50 & 0.33 & 1.83 & 6.79 \\
\hline 102 & Gresik Regency & 0.17 & 1.50 & 0.17 & 1.83 & 6.79 \\
\hline 103 & Sukabumi City & 0.83 & 0.92 & 0.08 & 1.83 & 6.79 \\
\hline 104 & Sragen Regency & 0.50 & 1.25 & 0.00 & 1.75 & 6.48 \\
\hline 105 & Jepara Regency & 0.83 & 0.92 & 0.00 & 1.75 & 6.48 \\
\hline 106 & Ciamis Regency & 0.00 & 0.92 & 0.67 & 1.58 & 5.86 \\
\hline 107 & Nganjuk Regency & 0.00 & 1.50 & 0.08 & 1.58 & 5.86 \\
\hline 108 & $\begin{array}{l}\text { Bandung Barat } \\
\text { Regency }\end{array}$ & 0.17 & 1.17 & 0.17 & 1.50 & 5.56 \\
\hline 109 & Serang City & 0.25 & 0.92 & 0.17 & 1.33 & 4.94 \\
\hline 110 & Sukabumi Regency & 0.42 & 0.92 & 0.00 & 1.33 & 4.94 \\
\hline 111 & Lumajang Regency & 0.08 & 1.00 & 0.08 & 1.17 & 4.32 \\
\hline 112 & Pamekasan Regency & 0.08 & 1.00 & 0.08 & 1.17 & 4.32 \\
\hline 113 & Tasikmalaya City & 0.08 & 1.00 & 0.00 & 1.08 & 4.01 \\
\hline 114 & Magetan Regency & 0.00 & 1.00 & 0.00 & 1.00 & 3.70 \\
\hline 115 & Madiun City & 0.00 & 1.00 & 0.00 & 1.00 & 3.70 \\
\hline 116 & Bekasi Regency & 0.08 & 0.92 & 0.00 & 1.00 & 3.70 \\
\hline 117 & Cianjur Regency & 0.00 & 0.92 & 0.00 & 0.92 & 3.40 \\
\hline 118 & Indramayu Regency & 0.00 & 0.92 & 0.00 & 0.92 & 3.40 \\
\hline 119 & Madiun Regency & 0.00 & 0.92 & 0.00 & 0.92 & 3.40 \\
\hline & Average & 2.13 & 2.41 & 0.74 & 5.29 & 19.59 \\
\hline
\end{tabular}

From table 4, it was known that Jakarta Capital City was ranked first in the transparency of regional financial management in Java in 2016. DKI Jakarta Province could have the highest score because the document indicator in reporting and accountability stage has been displayed update to the public while Bojonegoro Regency occupied the second position only showed a small portion of the document indicator of reporting and accountability stage. On the other hand, Madiun Regency had the lowest score in 2016, so Madiun Regency was ranked 119th in the transparency of regional financial management in Java in 2016. Table 4 also showed that the average score of transparency of local financial management in 2016 was still low at only 5.29 (19.59\%).

In addition, from table 4 it was also known that the stage most often fulfilled by 119 local governments in Java which website could be traced was the implementation stage. On the contrary, the least fulfilled stage was the stage of reporting and accountability. The higher scores at the implementation stage compared to the score at other stages were due in part to the high score on the information indicator of Procurement General Plan (RUP) where the 119 local governments in Java could present it.

Score for RUP information indicator tended to be high because announcing RUP was one of the stages in the procurement process of goods / services as mandated in Article 25 Paragraph 1 of Presidential Decree no. 4 of 2015 on the Fourth Amendment to Presidential Regulation no. 
54 of 2010 concerning Procurement of Government Goods / Services. The higher score of this indicator could be indicated more by the needs of the local government itself and the existence of mandatory rules, not because of awareness to realize transparency.

After assessing and ranking the transparency of local financial management, the next step was to categorize the level of information disclosure by using the Open Budget Index (OBI) to determine which local governments were included in categories of fairly open or not open enough. For the results of categorization level of information disclosure for fiscal year 2016 could be seen in table 5 .

Table 5. The Results of Budget Information Disclosure Category Year 2016

\begin{tabular}{|c|c|c|c|}
\hline $\begin{array}{c}\text { Level of } \\
\text { Budget } \\
\text { Openness }\end{array}$ & Category & Score & Name of Local Government \\
\hline \multirow[t]{2}{*}{ Sufficient } & Extensive & $81-100$ & - \\
\hline & Substantial & $61-80$ & - \\
\hline \multirow[t]{3}{*}{ Insufficient } & Limited & $41-60$ & $\begin{array}{l}\text { DKI Jakarta Province, Bojonegoro Regency, Central Java Province, } \\
\text { Malang Regency, East Java Province, Banyuwangi Regency, Magelang } \\
\text { City, Jombang Regency, Trenggalek Regency and Tegal Regency }\end{array}$ \\
\hline & Minimal & $21-40$ & $\begin{array}{l}\text { Yogyakarta Special Region, Bantul Regency, Batang Regency, } \\
\text { Yogyakarta City, Kudus Regency, Cilacap Regency, Pemalang Regency, } \\
\text { Banten Province, Demak Regency, Purworejo Regency, Magelang } \\
\text { Regency, Blitar Regency, Majalengka Regency, Sampang Regency, } \\
\text { Bondowoso Regency, West Java Province, Surabaya City, Bogor } \\
\text { Regency, Klaten Regency, Cirebon City, Rembang Regency, Blitar City, } \\
\text { Wonosobo Regency, Brebes Regency, Kabupaten Sidoarjo, Kabupaten } \\
\text { Lebak, Pekalongan Regency, Purbalingga Regency, Probolinggo } \\
\text { Municipality, Grobogan Regency, Pati Regency, Kuningan Regency, } \\
\text { Bekasi City, Surakarta City, Tulungagung Regency, Kulonprogo } \\
\text { Regency, and Tangerang City }\end{array}$ \\
\hline & $\begin{array}{l}\text { Sedikit } \\
\text { (Scant or } \\
\text { None) }\end{array}$ & $0-20$ & $\begin{array}{l}\text { Kabupaten Sukoharjo, Kabupaten Semarang, Kota Bogor, Kendal } \\
\text { Regency, Blora Regency, Banyumas Regency, Sleman Regency, } \\
\text { Pasuruan Regency, Salatiga City, Temanggung Regency, Serang } \\
\text { Regency, Bandung City, Mojokerto Regency, Situbondo Regency, } \\
\text { Kediri City, Malang City, Garut Regency, Semarang City, Karawang } \\
\text { Regency, Banjarnegara Regency, Gunungkidul Regency, Kebumen } \\
\text { Regency, Tangerang Regency, Tasikmalaya Regency, Pasuruan City, } \\
\text { Jember Regency, Pekalongan City, Ponorogo Regency, Cirebon } \\
\text { Regency, Pangandaran Regency, Lamongan Regency, Depok City, } \\
\text { Karanganyar Regency, Cilegon City, Bandung Regency, Wonogiri } \\
\text { Regency, Banjar City, Mojokerto City, Pandeglang Regency, Bangkalan } \\
\text { Regency, Purwakarta Regency, Sumenep Regency, Tuban Regency, } \\
\text { Cimahi City, Boyolali District, Tegal City, Batu City, Kediri Regency, } \\
\text { Subang Regency, Sumedang Regency, Pacitan Regency, Probolinggo } \\
\text { Regency, Tangerang Selatan City, Ngawi Regency, Gresik Regency, } \\
\text { Sukabumi City, Jepara Regency, Sragen Regency, Ciamis Regency, } \\
\text { Nganjuk Regency, West Bandung Regency, Serang City, Sukabumi } \\
\text { Regency, Lumajang Regency, Pamekasan Regency, Tasikmalaya City, } \\
\text { Magetan Regency, Madiun City, Bekasi Regency, Cianjur Regency, } \\
\text { Indramayu Regency, and Madiun Regency. }\end{array}$ \\
\hline
\end{tabular}

Source: data processed, 2017

Table 5 showed that none of the local governments in Java in 2016 were sufficient. All 
local governments in Java belonged to an insufficient budget disclosure rating with a limited qualification of 10 (ten) local governments, 37 local governments included in minimum qualification (minimum), and 72 local governments belonged to small qualification ( scant or none). This indicated that most local governments in Java still considered regional financial management information as something that was not important enough to be publicly displayed or better not communicated to the general public.

After assessing, ranking, and categorizing, further it was conducted the identification of local government characteristics which obtained the highest and lowest transparency of local financial management. The identification was conducted on 10 district / city governments with the highest transparency level and the identification was also conducted on 10 district / city governments with the lowest transparency level. The identification aimed to know the things that distinguished the district / city governments that got the highest and lowest predicate. The provincial government, which included the top 10 and the lowest 10, would not be included in the identification because in general the provincial government had different governmental conditions with the district / city so it could not be compared.

The identification was done on five aspects: the level of local welfare, local government wealth, Human Development Index (IPM), political competition, and press visibility. The identification was done by using literature review sourced from documents such as Local Government Financial Statements, District / Cities Books In Figures and on line media search pages associated with the theory of transparency or disclosure of financial information. The full results of identifying the characteristics of the district / city government could be seen in table 6 .

The level of regional welfare was measured from the Gross Regional Domestic Revenue (GRDR) per capita of the district / city government with the highest and lowest transparency index. Table 6 showed that district / city governments with the highest transparency index on average had higher levels of local welfare than those with the lowest transparency index. Regions that had a high level of welfare then the attention was not only focused on the problem of primary needs that have already fulfilled (Rahim and Martani 2015). This caused people to paid more attention to other things such as the implementation of government in their region, causing the demand for management accountability and transparency of local government was higher.

The wealth of local government which was measured by the Locally-generated revenue (PAD) ratio derived from the realization of the PAD of the district / city government was divided by the total revenue from the district / city government. Table 6 showed that district / city governments with high transparency indexes on average had higher PAD ratios than those with low transparency index. PAD showed how much local government could explore potential sources of income in the region. Local governments with high PAD tended to show their results to stakeholders because high performance regional governments were a signal of good public management (Puspita and Martani 2013).

Table 6 showed that district / city governments with the highest transparency index on average had a higher Human Development Index (HDI) than the district / city governments with the lowest transparency index. Improving human development could improve a better perspective for the community in overseeing its government and bringing forward good public governance in the region (Harnowati, 2017).

Political competition was measured by the number of DPRD members of the head region non-supporters party divided by the total DPRD members who served in the period of study. Table 6 showed that district / city governments with the highest transparency index on average had lower political competition than district / city governments with the lowest transparency index. This was due to the officers who were serving would try to show their best performance so they could get the attention from the community to keep picking them back in the coming period (Nosihana \& Yaya, 2016). In addition, looking at the average human development index that was directly proportional to the transparency index, it could be concluded that district / city governments in Java with high transparency index tended to have a more critical society 
against the running of government without having to join existing political parties. Therefore, the oversight against government was not limited to DPRDs or political parties.

Table 6.The Comparison between Regency / Municipality Government Characteristics and Highest and Lowest Transparency Levelof Year 2016

\begin{tabular}{|c|c|c|c|c|c|c|c|c|}
\hline \multirow[t]{2}{*}{$\begin{array}{l}\text { Transparency } \\
\text { Rating Status }\end{array}$} & \multirow[t]{2}{*}{$\begin{array}{c}\text { Name of } \\
\text { Regency } \\
\text { / City } \\
\text { Government }\end{array}$} & \multicolumn{2}{|c|}{$\begin{array}{c}\text { Regional Welfare Lecel (Per } \\
\text { Capita GDP) }\end{array}$} & \multicolumn{2}{|c|}{$\begin{array}{c}\text { Wealth } \\
\text { of Local } \\
\text { Government } \\
\text { (Ratio of } \\
\text { PAD) }\end{array}$} & \multirow[t]{2}{*}{ HDI } & \multirow[t]{2}{*}{$\begin{array}{c}\text { Political } \\
\text { Competition }\end{array}$} & \multirow[t]{2}{*}{$\begin{array}{c}\text { Press } \\
\text { Visibility }\end{array}$} \\
\hline & & 2014 & 2015 & 2014 & 2015 & & & \\
\hline \multirow[t]{11}{*}{ Higest } & $\begin{array}{l}\text { Bojonegoro } \\
\text { Regency }\end{array}$ & $41,012,000.00$ & $37,723,700.00$ & 0.12 & 0.12 & 66.17 & 0.64 & 30,80 \\
\hline & $\begin{array}{l}\text { Malang } \\
\text { Regency }\end{array}$ & $26,097,100.00$ & $29,023,000.00$ & 0.13 & 0.13 & 66.63 & 0.32 & 82,40 \\
\hline & $\begin{array}{l}\text { Banyuwangi } \\
\text { Regency }\end{array}$ & $33,629,400.00$ & $37,775,800.00$ & 0.12 & 0.12 & 68.08 & 0.68 & 50,70 \\
\hline & Magelang City & $49,047,224.64$ & $53,301,896.62$ & 0.22 & 0.24 & 76.39 & 0.64 & 43,10 \\
\hline & $\begin{array}{l}\text { Jombang } \\
\text { Regency }\end{array}$ & $21,335,800.00$ & $23,487,500.00$ & 0.16 & 0.17 & 69.59 & 0.66 & 39,60 \\
\hline & $\begin{array}{l}\text { Trenggalek } \\
\text { Regency }\end{array}$ & $17,906,700.00$ & $19,780,000.00$ & 0.09 & 0.1 & 67.25 & 0.42 & 34,60 \\
\hline & Tegal Regency & $16,137,155.25$ & $17,950,344.27$ & 0.14 & 0.14 & 65.04 & 0.76 & 42,30 \\
\hline & $\begin{array}{l}\text { Bantul } \\
\text { Regency }\end{array}$ & $18,378,230.54$ & $20,058,279.63$ & 0.2 & 0.2 & 77.99 & 0.78 & 47,70 \\
\hline & $\begin{array}{l}\text { Batang } \\
\text { Regency }\end{array}$ & $19,526,964.81$ & $21,583,845.83$ & 0.14 & 0.13 & 65.46 & 0.64 & 51,50 \\
\hline & $\begin{array}{l}\text { Yogyakarta } \\
\text { City }\end{array}$ & $61,620,213.60$ & $65,153,533.04$ & 0.32 & 0.36 & 84.56 & 0.5 & 119,00 \\
\hline & Average & $30,469,078.88$ & $32,583,789.94$ & 0.16 & 0.17 & 70.72 & 0.6 & 54,17 \\
\hline \multirow[t]{11}{*}{ Lowest } & $\begin{array}{l}\text { Sukabumi } \\
\text { Regency }\end{array}$ & $17,548,947.96$ & $19,281,003.96$ & 0.16 & 0.16 & 64.44 & 0.5 & 19,90 \\
\hline & $\begin{array}{l}\text { Lumajang } \\
\text { Regency }\end{array}$ & $21,418,200.00$ & $23,739,900.00$ & 0.13 & 0.12 & 63.02 & 0.78 & 21,20 \\
\hline & $\begin{array}{l}\text { Pamekasan } \\
\text { Regency }\end{array}$ & $13,248,200.00$ & $14,564,800.00$ & 0.11 & 0.1 & 63.1 & 0.31 & 20,70 \\
\hline & $\begin{array}{l}\text { Tasikmalaya } \\
\text { City }\end{array}$ & $20,806,196.91$ & $23,170,562.62$ & 0.16 & 0.15 & 69.99 & 0.6 & 25,00 \\
\hline & $\begin{array}{l}\text { Magetan } \\
\text { Regency }\end{array}$ & $20,051,800.00$ & $22,116,500.00$ & 0.1 & 0.11 & 71.39 & 0.73 & 16,70 \\
\hline & Madiun City & $52,841,900.00$ & $58,237,500.00$ & 0.14 & 0.17 & 79.48 & 0.59 & 23,30 \\
\hline & $\begin{array}{l}\text { Bekasi } \\
\text { Regency }\end{array}$ & $72,880,738.10$ & $75,799,495.69$ & 0.39 & 0.41 & 71.19 & 0.6 & 48,10 \\
\hline & $\begin{array}{l}\text { Cianjur } \\
\text { Regency }\end{array}$ & $12,939,509.60$ & $14,421,853.27$ & 0.13 & 0.12 & 62.42 & 0.72 & 16,20 \\
\hline & $\begin{array}{l}\text { Indramayu } \\
\text { Regency }\end{array}$ & $40,204,496.54$ & $38,660,721.30$ & 0.16 & 0.15 & 64.36 & 0.72 & 16,20 \\
\hline & $\begin{array}{l}\text { Madiun } \\
\text { Regency }\end{array}$ & $20,520,000.00$ & $18,590,000.00$ & 0.09 & 0.09 & 71.39 & 0.73 & 18,30 \\
\hline & Average & $29,245,998.91$ & $30,858,233.68$ & 0.16 & 0.16 & 68.08 & 0.63 & 22,56 \\
\hline
\end{tabular}

Source: data processed, 2017

Press visibility was measured by looking at quotes on the google search page with the keyword "transparency of local financial management" followed by the name of the local government. Table 6 showed that district / municipality governments with the highest transparency index on 
average had higher press visibility than local governments with the lowest transparency index. This showed the motivation of local government in disclosing financial information to the media (Dian and Haryanto 2013). Basically, media was used to play the role of moderator in agency relations between voters and local government.

The discussion of this study showed that 10 district / municipality governments in Java with the highest levels of transparency in local financial management had characteristics: higher welfare, higher local government wealth, higher HDI (Human Development Index), lower political competition and higher press visibility then ten district governments in Java with the lowest level of transparency in local financial management.

\section{CONCLUSIONS}

The average index of transparency in local government financial management in Java for fiscal year 2016 is still low at only $19.59 \%$. The result of the categorization of public information disclosure level according to the Open Budget Index (OBI) shows that for the fiscal year 2016 all local governments in Java are in insufficient category. This indicates that most local governments in Java still consider regional financial management information as something that is not important enough to be publicly displayed or better not communicated to the general public. In general, ten district / municipality governments in Java with the highest levels of transparency of local financial management have characteristics of the level of welfare, local government wealth, human development index (HDI), and press visibility which are higher and lower political competition compared to ten district / cities in Java with the lowest transparency of regional financial management.

The Ministry of Home Affairs in the future, can conduct an official assessment and ranking of local government financial management transparency and provide appropriate rewards or punishment so that local governments are motivated to perform better local financial management as it appears that local governments override the importance of transparency. Further research is expected to add the object of research so that it can see the ranking of transparency index of local financial management in Indonesia, determine the weighting for each criteria of measurement through interviews, focus group discussion, and expert validity and conduct a more comprehensive test to determine the factors that affect high low transparency levels of local financial management.

\section{REFERENCES}

Arista, D. (2015). Transparansi informasi situs web pemerintah daerah di sulawesi selatan sebagai implementasi keterbukaan informasi publik. Hasanuddin University. Retrieved from http://repository.unhas.ac.id/ handle/123456789/14625

Attila, G. (2012). Agency Problems in Public Sector. Journal of the University of Oradea : Economic Science, 1(1), 708-712.

Caba Pérez, M. del C., Rodríguez Bolívar, M. P., \& López Hernández, A. M. (2014). The determinants of government financial reports online. Transylvanian Review of Administrative Sciences, (42), 5-31.

Creswell, J. W. (2012). Educational research: Planning, conducting, and evaluating quantitative and qualitative research. Educational Research (Vol. 4). https://doi.org/10.1017/СBO9781107415324.004

Dian, R. A., \& Haryanto. (2013). Faktor-Faktor Yang Mempengaruhi Pengungkapan Informasi Akuntansi Di Internet Oleh Pemerintah Daerah. http://eprints.undip.ac.id/39616/. Diponegoro University.

Harnowati, A. I. P. (2017). Determinan Pengungkapan Laporan Keuangan Pemerintah Daerah Di Indonesia. Lampung University. Retrieved from http://digilib.unila.ac.id/id/eprint/25596

Hermana, B., Tarigan, A., Medyawati, H., \& Silfianti, W. (2012). E-Government Implementation in Indonesia : Financial Transparency on the Web. 3rd - International Conference on E-Education, E-Business, E-Management and E-Learning IPEDR, 27, 194-199.

Huwae, K. (2016). Analisis Tingkat Keterbukaan Informasi Pengelolaan Keuangan Daerah (Studi di Provinsi Daerah Istimewa Yogyakarta). Universitas Gadjah Mada.

Ibrahim. (2015). Metode Penelitian Kualitatif. Bandung: Alfabeta.

Jensen, M. C., \& Meckling, W. H. (1976). Theory of the Firm: Managerial Behavior, Agency Costs and 
Ownership Structure. Journal of Financial Economics, 3(4), 305-360. https://doi.org/http://dx.doi. org/10.1016/0304-405X(76)90026-X

Johnston, M. (2006). Good governance: Rule of law, transparency, and accountability. New York: United Nations Public Administration Network. New York: United Nations Public Administration Network.

Lane, J.-E. (2013). The Principal-Agent Approach to Politics: Policy Implementation and Public PolicyMaking. Open Journal of Political Science, 3(2), 85-89.

Marais, D. L., Quayle, M., \& Burns, J. K. (2017). The Role Of Access To Information In Enabling Transparency And Public Participation In Governance-A Case Study Of Access To Policy Consultation Records In South Africa. African Journal of Public Affairs, 9(6), 36-49.

Martani, D., \& Fitriasari, D. (2014). Financial and Performance Transparency on the Local Government Website in Indonesia. Journal of Theoretical and Applied Information Technology, 60(3), 504-516.

Maulana, M. (2013). Budget Brief Indeks Keterbukaan Badan Publik. Jakarta: SEKNAS FITRA.

Nosihana, A., \& Yaya, R. (2016). Internet Financial Reporting dan Faktor-Faktor yang Mempengaruhinya Pada Pemerintah Kota dan Kabupaten Di Indonesia. Jurnal Dinamika Akuntansi Dan Bisnis, 3(2), 89-104.

Puspita, R., \& Martani, D. (2013). Analisa Pengaruh Kinerja dan Karakteristik Pemda Terhadap Tingkat Pengungkapan dan Kualitas Informasi Dalam Website Pemda. Journal of Chemical Information and Modeling, 53(9), 1689-1699. https://doi.org/10.1017/CBO9781107415324.004

Rahim, W. M., \& Martani, D. (2015). Analisis Pengaruh Tingkat Akses Internet, Kompetisi Politik, Opini Audit, Karakteristik Pemda, Dan Karakteristik Demografi Terhadap Pengungkapan Informasi Keuangan Dan Non-Keuangan Website Pemerintah Daerah. Indonesia University. Retrieved from https://staff.blog. ui.ac.id/martani/2016/04/21/analisis-faktor-yang-mempengaruhi-website-pemda/

Sargiacomo, M., \& Gomes, D. (2011). Accounting And Accountability In Local Government: Contributions From Accounting History Research. Accounting History, 16(3), 253-290.

Soepriyanto, G., \& Aristiani, R. (2011). Evaluasi Pengungkapan Laporan Keuangan Daerah di Situs Internet : Studi pada Pemerintah Daerah Indonesia. Jurnal Binus Business Review, 2(1), 192-201.

Syamsul, S., \& Ritonga, I. T. (2017). Pengaruh Tata Kelola Pemerintah Daerah Terhadaptransparansi Pengelolaan Keuangan Daerah: Bukti Empiris Pada Pemerintah Provinsi Di Indonesia. Jurnal Akuntansi, 21(3), 448-460.

Tayib, M., Coombs, H. M., \& Ameen, J. R. M. (1999). Financial Reporting By Malaysian Local Authorities: A Study Of The Needs And Requirements Of The Users Of Local Authority Financial Accounts. International Journal of Public Sector Management, 12(2), 103-121.

UNESCAP. (2009). What is Good Governance ? United Nations Economic and Social Comission for Asia and the Pacific, 1-3. https://doi.org/10.1016/B978-012397720-5.50034-7

Yusuf, J.-E., \& Jordan, M. M. (2015). Popular Financial Reports: Tools for Transparency, Accountability and Citizen Engagement. The Journal of Government Financial Management, 64(1), 12-17. 